\title{
Application of Molecular Hydrogen as an Antioxidant in Responses to Ventilatory and Ergogenic Adjustments during Incremental Exercise in Humans
}

\author{
Ahad Abdulkarim D. Alharbi ${ }^{1}$, Naoyuki Ebine ${ }^{1}$, Satoshi Nakae ${ }^{2}$, Tatsuya Hojo ${ }^{1}$ and Yoshiyuki Fukuoka ${ }^{1, *}$ \\ 1 Graduate School of Health and Sports Science, Doshisha University, Kyoto 610-0394, Japan; \\ cyhf0001@mail4.doshisha.ac.jp (A.A.D.A.); nebine@mail.doshisha.ac.jp (N.E.); \\ thojo@mail.doshisha.ac.jp (T.H.) \\ 2 Division of Bioengineering, Graduate School of Engineering Science, Osaka University, \\ Osaka 560-8531, Japan; snakae@bpe.es.osaka-u.ac.jp \\ * Correspondence: yfukuoka@mail.doshisha.ac.jp; Tel.: +81-774-65-7530; Fax: +81-774-65-6029
}

Citation: Alharbi, A.A.D.; Ebine, N.; Nakae, S.; Hojo, T.; Fukuoka, Y. Application of Molecular Hydrogen as an Antioxidant in Responses to Ventilatory and Ergogenic Adjustments during Incremental Exercise in Humans. Nutrients 2021, 13, 459. https://doi.org/10.3390/ nu13020459

Academic Editor: Fabio Galvano Received: 22 December 2020

Accepted: 26 January 2021

Published: 30 January 2021

Publisher's Note: MDPI stays neutral with regard to jurisdictional claims in published maps and institutional affiliations.

Copyright: (c) 2021 by the authors. Licensee MDPI, Basel, Switzerland. This article is an open access article distributed under the terms and conditions of the Creative Commons Attribution (CC BY) license (https:/ / creativecommons.org/licenses/by/ $4.0 /)$.

\begin{abstract}
We investigated effects of molecular hydrogen $\left(\mathrm{H}_{2}\right)$ supplementation on acid-base status, pulmonary gas exchange responses, and local muscle oxygenation during incremental exercise. Eighteen healthy, trained subjects in a randomized, double-blind, crossover design received $\mathrm{H}_{2}$-rich calcium powder (HCP) $\left(1500 \mathrm{mg} /\right.$ day, containing $2.544 \mu \mathrm{g} /$ day of $\left.\mathrm{H}_{2}\right)$ or $\mathrm{H}_{2}$-depleted placebo $(1500 \mathrm{mg} /$ day) for three consecutive days. They performed cycling incremental exercise starting at 20-watt work rate, increasing by 20 watts $/ 2$ min until exhaustion. Breath-by-breath pulmonary ventilation $\left(\dot{\mathrm{V}}_{\mathrm{E}}\right)$ and $\mathrm{CO}_{2}$ output $\left(\dot{\mathrm{VCO}}_{2}\right)$ were measured and muscle deoxygenation (deoxy $[\mathrm{Hb}+\mathrm{Mb}]$ ) was determined via time-resolved near-infrared spectroscopy in the vastus lateralis (VL) and rectus femoris (RF). Blood gases' $\mathrm{pH}$, lactate, and bicarbonate $\left(\mathrm{HCO}_{3}{ }^{-}\right)$concentrations were measured at rest and 120-, 200-, and 240-watt work rates. At rest, the HCP group had significantly lower $\dot{\mathrm{V}}_{\mathrm{E}}, \dot{\mathrm{V} C \mathrm{CO}_{2}}$, and higher $\mathrm{HCO}_{3}{ }^{-}$, partial pressures of $\mathrm{CO}_{2}\left(\mathrm{PCO}_{2}\right)$ versus placebo. During exercise, a significant $\mathrm{pH}$ decrease and greater $\mathrm{HCO}_{3}{ }^{-}$continued until 240-watt workload in $\mathrm{HCP}$. The $\dot{\mathrm{V}}_{\mathrm{E}}$ was significantly lower in $\mathrm{HCP}$ versus placebo, but $\mathrm{HCP}$ did not affect the gas exchange status of $\mathrm{VCO}_{2}$ or oxygen uptake $\left(\mathrm{V}_{2}\right)$. HCP increased absolute values of deoxy[Hb $\left.+\mathrm{Mb}\right]$ at the RF but not VL. Thus, HCP-induced hypoventilation would lead to lower $\mathrm{pH}$ and secondarily impaired balance between $\mathrm{O}_{2}$ delivery and utilization in the local RF during exercise, suggesting that HCP supplementation, which increases the at-rest antioxidant potential, affects the lower ventilation and $\mathrm{pH}$ status during incremental exercise. HPC induced a significantly lower $\mathrm{O}_{2}$ delivery/utilization ratio in the RF but not the $\mathrm{VL}$, which may be because these regions possess inherently different vascular/metabolic control properties, perhaps related to fiber-type composition.
\end{abstract}

Keywords: hydrogen supplement; acid status; muscle deoxygenation; ventilation; incremental exercise

\section{Introduction}

Molecular hydrogen $\left(\mathrm{H}_{2}\right)$ is a colorless, tasteless, odorless, and minimal molecule with high flammability [1]. Most mammals, including humans, do not synthesize hydrogenase, which is a catalyst for the activation of $\mathrm{H}_{2}$ [2]. In sports science, there is limited research regarding the antioxidant effect of $\mathrm{H}_{2}$ on exercise-induced oxidative stress. Unlike conventional antioxidants, $\mathrm{H}_{2}$ is a gas molecule and as such it is believed to have several advantages for application in sports science [3-5]. $\mathrm{H}_{2}$ is the smallest molecule and thus can penetrate the cellular membrane and rapidly diffuse into organelles (e.g., mitochondria). $\mathrm{H}_{2}$ is thought to have no effect on physiologically reactive species (e.g., $\mathrm{H}_{2} \mathrm{O}_{2}$ ), as it can selectively reduce $\bullet \mathrm{OH}$ and $\mathrm{ONOO}^{-}$[6]. In addition, $\mathrm{H}_{2}$ can be supplied to the body through multiple routes of administration, such as the oral intake of $\mathrm{H}_{2}$ water, $\mathrm{H}_{2}$ bathing, an intravenous infusion of $\mathrm{H}_{2}$ saline, and the inhalation of $\mathrm{H}_{2}$ gas. 
In addition to these advantages, $\mathrm{H}_{2}$ can be used with minimal side effects as it is excreted by exhaling. If $\mathrm{H}_{2}$ is absorbed well in the intestinal tract, it will lead to an increase in bicarbonate ion $\left(\mathrm{HCO}_{3}{ }^{-}\right)$as well as a reduction in reactive oxygen species (ROS). Aoki et al. (2012) initially reported that in trained young men, an oral intake of $\mathrm{H}_{2}$ water suppressed the elevation of blood lactate concentrations and reduced peak torque during exercise [7]. Thus, $\mathrm{H}_{2}$ water leads to a strong buffering capacity to glucose metabolism and/or exercise performance. We, thus, hypothesized that the intake of $\mathrm{H}_{2}$ would promote buffering lactic acid and lead to higher $\mathrm{pH}$, which would induce delayed metabolic acidosis and extend exercise performance. The prior studies mostly used $\mathrm{H}_{2}$ in gas or infused water forms, but we developed a new chemical engineering technique for hydro-calcium powder (HCP) that uses extracted calcium to absorb highly concentrated hydrogen molecules (International Patent No. 4,472,022).

In investigations of the relationship between muscle $\mathrm{O}_{2}$ delivery $\left(\mathrm{Q}_{2}\right)$ and oxygen uptake ( $\dot{\mathrm{VO}}_{2}$ ), time-resolved near-infrared spectroscopy (TR-NIRS) was able to resolve the absolute values of [heme] chromophores [8] and provided improved mechanistic insights into the effects of $\mathrm{HCP}$ on muscle $\mathrm{QO}_{2}$-to- $\mathrm{VO}_{2}$ relationships. It is also presently unclear whether dietary HCP supplementation might alter the muscle spatial heterogeneity in muscle deoxygenation (deoxy[Hb $+\mathrm{Mb}]$ ) kinetics (and, by extension, $\dot{\mathrm{QO}}_{2}$-to- $\dot{\mathrm{VO}}_{2}$ matching) that was observed during cycling exercise [8-15]. $\mathrm{HCP}$ may increase $\mathrm{HCO}_{3}{ }^{-}$ and delay metabolic acidosis. As described above, since HCP causes opposite effects at the same time, the extent of change that HCP causes in the muscle spatial heterogeneity in deoxy $[\mathrm{Hb}+\mathrm{Mb}]$ kinetics at different muscle sites is not yet known.

The aforementioned advantages of $\mathrm{H}_{2}$ use are expected to be a potential scavenger of superoxide anions, as it was reported that the augmented hypoxic carotid body sensory response was abolished in a group of rats pretreated with a superoxide dismutase mimetic $[16,17]$. Wilkerson et al. also demonstrated that the intravenous administration of a superoxide anion scavenger to anesthetized, vagotomized, and ventilated rats before their exposure to acute hypoxia abolished the long-term facilitation (LTF) of phrenic nervous activity [18]. Given these findings in animals, one of the possibilities is that ROS are downregulated by the administration of molecular hydrogen, resulting in hypoventilation and blood hypercapnia. We, therefore, hypothesized that the administration of a strong antioxidant of molecular hydrogen would reduce the magnitude of ventilatory and deoxy $[\mathrm{Hb}+\mathrm{Mb}]$ responses before and during exhaustive exercise in humans.

To test these contradictory hypotheses, we conducted the present study to determine whether an HCP supplement causes different responses to muscle deoxy[ $\mathrm{Hb}+\mathrm{Mb}]$ and the responses of pulmonary ventilatory and blood gas values at both rest and incremental exercise compared to placebo.

\section{Subjects and Methods}

\subsection{Subjects}

Eighteen healthy males with no cardiac, ventilatory, gas exchange, or musculoskeletal disorders participated. Their mean \pm SD values were age, $21 \pm 1$ years old; height, $174.0 \pm 4.4 \mathrm{~cm}$; and body weight, $66.6 \pm 6.3 \mathrm{~kg}$. Written, informed consent was obtained from all subjects after a detailed explanation of all procedures, the purpose of the study, the possible risks, and the benefits of participation. Our study conformed to the Declaration of Helsinki, and the ethical committee of Doshisha University approved all study procedures (No. 18012).

\subsection{Supplements}

Each subject was examined twice in a crossover, double-blind manner and given four capsules/day for three days of either $\mathrm{H}_{2}$-rich calcium powder (HCP) supplements (ENAGEGATE, Tokyo) or calcium powder as a placebo (ENAGEGATE). The capsules for both HCP and placebo were identical, with a clear outer shell and white powder fill inside. Each capsule weighted approx. $633 \mathrm{mg}$, with $375 \mathrm{mg}$ of either HCP or only calcium powder 
for the placebo. The amount of hydrogen in the HCP was $0.636 \mu \mathrm{g} /$ capsule. The subjects were instructed to consume the supplements in one dose of four capsules at 9:00 p.m. $( \pm 1 \mathrm{~h})$ for the three consecutive days prior to the experiment day, amounting to the total $\mathrm{H}_{2}$ amount of $2.544 \mu \mathrm{g} /$ day.

\subsection{Experimental Overview}

The subjects were familiarized with all of the measurement techniques, including the cycling exercise with a face mask. A familiarization test was conducted 1-2 weeks prior to the start of the experiments, and the experiments were separated by a six- to seven-day washout/rest period.

On the day prior to testing, the consumption of alcohol and caffeine was prohibited, and when the exercise or training was carried out, the intensity, the timing, and duration were matched for both experiments. The subjects were also instructed to record and replicate their dietary intake for dinner the previous night and for breakfast before the testing. The subjects consumed breakfast at home $\geq 6 \mathrm{~h}$ prior to the start of the experiment (and were instructed to replicate it from their dietary intake report). At $3 \mathrm{~h}$ before the experiment, the subjects ate a small meal consisting of the Calorie Mate (four blocks, Otsuka Pharmaceutical, Tokyo) and one bottle of caffeine-free barely tea (Healthy Mineral Barley Tea, $600 \mathrm{~mL}$, ITO EN, Tokyo) that was standardized for all subjects, in order to avoid hunger and minimize fluctuations in significant blood metabolic parameters (specifically blood glucose) among/within subjects.

All studies were conducted in a custom-made environmental chamber (LP-2.5PH-SS, NKsystem, Osaka, Japan) maintained at a temperature of $25^{\circ} \mathrm{C}$ with $50 \%$ relative humidity with minimal external stimuli.

The subjects performed an incremental exercise test using a cycle ergometer (75XL-III; Konami, Tokyo). The exercise started with $2 \mathrm{~min}$ at the workload of $20 \mathrm{~W}$, after which the workload was increased at $20 \mathrm{~W} / 2$ min until the subject's exhaustion or $300 \mathrm{~W}$ was reached, and the subjects were instructed to maintain their pedal frequency at $60 \mathrm{rpm}$ throughout the exercise. When given criteria were met (e.g., a plateau or a drop in $\dot{\mathrm{VO}}_{2}$, a heart rate $(\mathrm{HR})>95 \%$ of the age-predicted maximum [19], or a respiratory exchange ratio $>1.1$ ), the highest average value of $1-\mathrm{min}_{\mathrm{V}} \mathrm{O}_{2}$ was regarded as the individual's peak oxygen uptake [20].

\subsection{Analyses of Blood Metabolites}

A peripheral venous catheter was placed in the subject's forearm to allow free movement of his elbow and hands during the experiment, and a 100- $\mu \mathrm{L}$ blood sample was collected at four time points: pre-exercise and at 120, 200, and $240 \mathrm{~W}$ during the incremental exercise. The blood samples were analyzed for blood gas, electrolytes, and the metabolic profile with a portable blood analysis system (epoc ${ }^{\circledR}$, Siemens Healthcare, Tokyo) for the determination of blood gases, acid status of $\mathrm{pH}$, bicarbonate $\left(\mathrm{HCO}_{3}{ }^{-}\right)$, and blood properties of hemoglobin $(\mathrm{Hgb})$ and hematocrit $(\mathrm{Hct}) . \mathrm{HCO}_{3}{ }^{-}$was calculated from the partial pressures of $\mathrm{CO}_{2}\left(\mathrm{PCO}_{2}\right)$ and $\mathrm{pH}$ values according to the Henderson-Hasselbalch equation, and the base excess (BEecf) was calculated according to the following equation [21]:

$$
\mathrm{BE}=(1-0.014 \times[\mathrm{Hb}]) \times\left(\left[\mathrm{HCO}_{3}{ }^{-}\right]-24.8+(1.43 \times[\mathrm{Hgb}]+7.7) \times(\mathrm{pH}-7.4)\right)
$$

The metabolic status of lactate (Lac), glucose (Glu), and creatinine (Crea), the electrolytes of the serum sodium $\left(\mathrm{Na}^{+}\right)$, potassium $\left(\mathrm{K}^{+}\right)$, chloride $\left(\mathrm{Cl}^{-}\right)$concentrations, $\bullet$ and the Aniongap (AGap) and Aniongap potassium (AGapK) were calculated by electrolyte parameters.

\subsection{Measurements}

Each subject's pulmonary gas exchange was measured breath by breath throughout all tests as described $[13,22,23]$. The breath-by-breath gas exchange system (AE-310s; Minato 
Medical Sciences, Osaka) was calibrated according to the manufacturer's recommendation before each exercise test. The subject breathed through a lower-resistance mouthpiece connected to a hot wire flowmeter for the measurement of inspiratory and expiratory flow and volume. Inspired and expired gases were continuously sampled from the subject's mouth, and the $\mathrm{O}_{2}$ and $\mathrm{CO}_{2}$ fractional concentration were measured by fast-responding paramagnetic and infrared analyzers, respectively. The gas volume and concentration signals were time-aligned to account for the time lag between the signals for the calculation of the gas exchange parameters on a breath-by-breath basis. Alveolar gas exchange variables were calculated according to the algorithms of Beaver et al. [24]. The breath-by-breath $\dot{\mathrm{V}}_{\mathrm{E}}$ (BTPS), $\dot{\mathrm{VO}}_{2}$ (STPD), $\dot{\mathrm{VCO}}_{2}$ (STPD), gas exchange ratio (R), and end-tidal $\mathrm{CO}_{2}$ pressure $\left(\mathrm{P}_{\mathrm{ET}} \mathrm{CO}_{2}\right)$ were determined.

The electrocardiogram (ECG), taken from a V5 lead, was monitored continuously on a wireless ECG monitor (DS-2150; Fukuda Denshi, Tokyo), and subject's HR was measured by beat-by-beat counting of the R-spike of the ECG taken simultaneously with the other measurements.

The absolute values of oxygenated $(\mathrm{oxy}[\mathrm{Hb}+\mathrm{Mb}])$ and deoxygenated (deoxy $[\mathrm{Hb}+\mathrm{Mb}])$ and the total hemoglobin and myoglobin concentration (total[ $\mathrm{Hb}+\mathrm{Mb}]$ ) were sampled from the vastus lateralis (VL) and rectus femoris (RF) muscles of the subject's dominant leg by a TR-NIRS system (C12707, Hamamatsu Photonics, Hamamatsu, Japan). This system measures the distribution of in vivo optical path lengths, thereby enabling the determination of the absolute $[\mathrm{Hb}+\mathrm{Mb}]$ concentration $\left(\mu \mathrm{mol} \cdot \mathrm{L}^{-1}\right)$. The deoxygenation measured by the TR-NIRS was demonstrated to correlate significantly with the oxyhemoglobin saturation in both the blood and a purified-hemoglobin phantom solution $[10,25,26]$.

The optodes were housed in black rubber holders that helped to minimize extraneous movement, thus ensuring that the position of the optodes was fixed and invariant. The distal optodes were placed on the lower third of the VL and the RF muscles parallel to the major axis of the thigh. The location of the distal optodes on the VL muscle was chosen to represent the single-site TR-NIRS measurement conducted in previous studies [27-29]. The proximal optode pairs on the VL and the RF muscles were located $\sim 10-15 \mathrm{~cm}$ from the distal optode pairs. The interoptode spacing between the emitter and the receiver was $3 \mathrm{~cm}$. The depth of the measured area was assumed to be approximately one-half of the distance between the emitter and the receiver, $\sim 1.5 \mathrm{~cm}$.

The skin under the probes was carefully shaved. Pen marks were made on the skin to indicate the margins of the rubber holder to check for any downward sliding of the probe during cycling and for accurate probe repositioning on subsequent days. No sliding was observed in any subject at the end of each protocol. The principles of operation and the algorithms used by the equipment are described in detail elsewhere [30,31]. Calibration of both instruments was performed before each test by measuring the response when the input and receiving fibers faced each other through a neutral-density filter in a black tube.

At the end of the exercise test, pen marks were made on the subject's skin to indicate the margins of the TR-NIRS optode holders to reposition the probes for subsequent laboratory visits. The adipose tissue thickness (ATT) and muscle thickness were measured using B-mode ultrasound (SSD-3500SV, Hitachi-Aloka Medical, Tokyo) with the subject at rest and seated in an upright position. To quantify the influence of ATT on dynamic changes in TR-NIRS signals, we used the ATT correction method of Bowen et al. (2013) [11]. With this method, the tissue $\mathrm{O}_{2}$ saturation $\left(\mathrm{S}_{\mathrm{t}} \mathrm{O}_{2}\right)$ was calculated using oxy[Hb $\left.+\mathrm{Mb}\right] /$ total $[\mathrm{Hb}+\mathrm{Mb}$.

\subsection{Data Analysis}

The peak values for gas exchange/ventilation were detected and then averaged for $30 \mathrm{~s}$ at the peak. Similarly, the baseline (resting) values of gas exchange/ventilation were calculated as the mean value over the final $30 \mathrm{~s}$ of the rest period. The output frequency of both TR-NIRS systems was set to $1 \mathrm{~Hz}$ and averaged post hoc to increase the signal-to-noise ratio, providing one measurement every $5 \mathrm{~s}$. The baseline of each TR-NIRS measurement was calculated as the mean value of the $30 \mathrm{~s}$ prior to the start of the incremental exercise. 
The absolute values of gas exchange/ventilation and absolute muscle deoxy[ $\mathrm{Hb}+\mathrm{Mb}]$, $\operatorname{oxy}[\mathrm{Hb}+\mathrm{Mb}]$, and total $[\mathrm{Hb}+\mathrm{Mb}]$ measurement were then calculated every $20 \mathrm{~W}$ from $20 \mathrm{~W}$ to the maximal exercise for each subject. The value for each variable at each $20-\mathrm{W}$ increment was calculated as the last $60 \mathrm{~s}$ from the initial $20 \mathrm{~W}$ to $240 \mathrm{~W}$. Blood gas and metabolic profiles were obtained three times (at 120, 200, and $240 \mathrm{~W}$ ). Since there were individual differences in the exhausted exercise duration despite the absence of a difference between the HCP and placebo groups, we made data arrangements at up to $240 \mathrm{~W}$ of each blood gas sample.

\subsection{Statistical Analysis}

All data are expressed as the mean \pm standard deviation (SD) and were analyzed using the statistical package IBM SPSS, PC program, ver. 25.0 (IBM, Tokyo, Japan). We compared the peak values of gas exchange, overall exercise time, and mean values of parameters at rest between the HCP and placebo groups, using a paired t-test. The significance of differences in each variable was determined by a two-way analysis of variance (ANOVA), comparing supplements $(\mathrm{HCP}$ and placebo $) \times$ work rates $(20-240 \mathrm{~W})$. A post hoc comparison was applied by Bonferroni test for the appropriate data sets when a significant $F$-value was obtained. Probability $(p)$-values $<0.05$ were considered significant.

\section{Results}

\subsection{At Rest}

The mean values of the ventilatory, acid-base, and TR-NIRS profiles are presented in Table 1 . The mean values of the ventilatory parameters displayed a significantly lower $\dot{\mathrm{V}}_{\mathrm{E}}$ $(p<0.05), \dot{\mathrm{VO}}_{2}(p<0.01)$, and $\dot{\mathrm{V} C O}{ }_{2}(p<0.05)$ in the HCP group compared to the placebo group, whereas no significant difference in HR or R was observed between the HCP and placebo groups.

Table 1. Mean values of ventilatory, acid-base, and NIRS profiles at rest condition between the HCP and placebo groups.

\begin{tabular}{|c|c|c|c|c|c|c|c|}
\hline \multirow{2}{*}{ metabolic gas exchange } & \multicolumn{3}{|c|}{ HCP } & \multicolumn{3}{|c|}{ Placebo } & \multirow[t]{2}{*}{$p$ Value } \\
\hline & & & & & & & \\
\hline $\mathrm{V}_{\mathrm{E}}\left(\mathrm{L} \cdot \min ^{-1}\right)$ & 11.8 & \pm & 3.1 & 13.2 & \pm & 3.2 & $0.02 *$ \\
\hline $\mathrm{VO}_{2}\left(\mathrm{~mL} \cdot \mathrm{min}^{-1}\right)$ & 355 & \pm & 109 & 429 & \pm & 136 & $0.01 *$ \\
\hline $\mathrm{VCO}_{2}\left(\mathrm{~mL} \cdot \mathrm{min}^{-1}\right)$ & 306 & \pm & 96 & 364 & \pm & 130 & $0.03 *$ \\
\hline HR (beats. $\min ^{-1}$ ) & 75.3 & \pm & 12.3 & 78.5 & \pm & 15.2 & 0.14 \\
\hline $\mathrm{R}$ & 0.9 & \pm & 0.1 & 0.8 & \pm & 0.1 & 0.22 \\
\hline \multicolumn{8}{|l|}{ blood gas } \\
\hline $\mathrm{pH}$ & 7.356 & \pm & 0.04 & 7.376 & \pm & 0.04 & $0.048^{*}$ \\
\hline $\mathrm{PO}_{2}(\mathrm{mmHg})$ & 43.9 & \pm & 19.3 & 51.0 & \pm & 17.8 & 0.107 \\
\hline $\mathrm{PCO}_{2}(\mathrm{mmHg})$ & 52.4 & \pm & 8.3 & 47.4 & \pm & 8.2 & $0.026^{*}$ \\
\hline $\mathrm{HCO}_{3}{ }^{-}\left(\mathrm{mmol} \cdot \mathrm{L}^{-1}\right)$ & 29.1 & \pm & 2.2 & 27.5 & \pm & 2.6 & 0.041 * \\
\hline $\mathrm{SO}_{2}(\%)$ & 66.8 & \pm & 25.2 & 76.9 & \pm & 19.7 & 0.051 \\
\hline $\mathrm{BE}(\mathrm{ecf})\left(\mathrm{mmol} \cdot \mathrm{L}^{-1}\right)$ & 3.6 & \pm & 1.9 & 2.4 & \pm & 2.3 & 0.071 \\
\hline $\mathrm{TCO}_{2}\left(\mathrm{mmol} \cdot \mathrm{L}^{-1}\right)$ & 30.7 & \pm & 2.5 & 29 & \pm & 2.8 & $0.041 *$ \\
\hline Hct $(\%)$ & 46 & \pm & 2.4 & 46 & \pm & 3.1 & 0.328 \\
\hline $\operatorname{Hgb}(\mathrm{g} / \mathrm{dL})$ & 15.8 & \pm & 0.8 & 15.6 & \pm & 1.1 & 0.313 \\
\hline \multicolumn{8}{|l|}{ electrolytes } \\
\hline $\mathrm{Na}^{+}\left(\mathrm{mmol} \cdot \mathrm{L}^{-1}\right)$ & 141 & \pm & 1.6 & 141 & \pm & 1.7 & 0.069 \\
\hline $\mathrm{K}^{+}\left(\mathrm{mmol} \cdot \mathrm{L}^{-1}\right)$ & 3.8 & \pm & 0.3 & 4 & \pm & 0.2 & 0.062 \\
\hline $\mathrm{Ca}^{2+}\left(\mathrm{mmol} \cdot \mathrm{L}^{-1}\right)$ & 1.26 & \pm & 0 & 1.25 & \pm & 0.0 & 0.471 \\
\hline $\mathrm{Cl}^{-}\left(\mathrm{mmol} \cdot \mathrm{L}^{-1}\right)$ & 105 & \pm & 1.7 & 106 & \pm & 1.8 & $0.011 *$ \\
\hline AGap $\left(\mathrm{mmol} \cdot \mathrm{L}^{-1}\right)$ & 7 & \pm & 1.6 & 7 & \pm & 2.2 & 0.444 \\
\hline AGapK $\left(\mathrm{mmol} \cdot \mathrm{L}^{-1}\right)$ & 11 & \pm & 1.6 & 11 & \pm & 2.3 & 0.365 \\
\hline
\end{tabular}


Table 1. Cont.

\begin{tabular}{|c|c|c|c|c|c|c|c|}
\hline \multirow{2}{*}{ metabolic status } & \multicolumn{3}{|c|}{ HCP } & \multicolumn{3}{|c|}{ Placebo } & \multirow[t]{2}{*}{$p$ Value } \\
\hline & & & & & & & \\
\hline Lac $\left(\mathrm{mmol} \cdot \mathrm{L}^{-1}\right)$ & 1.13 & \pm & 0.4 & 1.28 & \pm & 0.6 & 0.312 \\
\hline Glu $\left(\mathrm{mg} \cdot \mathrm{dL}^{-1}\right)$ & 98 & \pm & 14.1 & 104 & \pm & 21.2 & 0.165 \\
\hline Crea $\left(\mathrm{mg} \cdot \mathrm{dL}^{-1}\right)$ & 0.96 & \pm & 0.1 & 0.92 & \pm & 0.2 & 0.212 \\
\hline \multicolumn{8}{|l|}{ TR-NIRS in the RF muscle } \\
\hline Total $[\mathrm{Hb}+\mathrm{Mb}](\mu \mathrm{M})$ & 206 & \pm & 48 & 201 & \pm & 37 & 0.469 \\
\hline Deoxy $[\mathrm{Hb}+\mathrm{Mb}](\mu \mathrm{M})$ & 96 & \pm & 22 & 85 & \pm & 23 & 0.045 * \\
\hline $\mathrm{StO}_{2}(\%)$ & 53 & \pm & 8 & 57 & \pm & 12 & 0.028 * \\
\hline \multicolumn{8}{|l|}{ TR-NIRS in the VL muscle } \\
\hline Total $[\mathrm{Hb}+\mathrm{Mb}](\mu \mathrm{M})$ & 200 & \pm & 37 & 212 & \pm & 37 & 0.164 \\
\hline $\operatorname{Deoxy}[\mathrm{Hb}+\mathrm{Mb}](\mu \mathrm{M})$ & 76 & \pm & 20 & 76 & \pm & 22 & 0.877 \\
\hline $\mathrm{StO}_{2}(\%)$ & 61 & \pm & 12 & 63 & \pm & 12 & 0.222 \\
\hline
\end{tabular}

Data are shown as mean \pm standard deviation (SD). Significant difference between HCP and placebo $\left({ }^{*} p<0.05\right)$

With the blood gas status related to metabolism, the HCP group showed the following significant differences from the placebo group: lower $\mathrm{pH}$ (HCP: $7.356 \pm 0.04$ vs. placebo: $7.376 \pm 0.04, p<0.05)$ and higher $\mathrm{PCO}_{2}(52.4 \pm 8.3$ vs. $47.4 \pm 8.2 \mathrm{mmHg}, p<0.05)$ and $\mathrm{HCO}_{3}{ }^{-}\left(29.1 \pm 2.2\right.$ vs. $\left.27.5 \pm 2.6 \mathrm{mmol} \cdot \mathrm{L}^{-1}, p<0.05\right)$. The metabolic profile as Lac or Glu was within the standard range at rest with no significant difference between the HCP and placebo groups.

The TR-NIRS profiles at the RF muscle revealed significantly lower deoxy[Hb $+\mathrm{Mb}]$ $(p<0.05)$ and $\mathrm{S}_{\mathrm{t}} \mathrm{O}_{2}(p<0.05)$ values, whereas the VL muscle showed no significant difference in either the $\mathrm{HCP}$ or placebo group.

\subsection{During Incremental Exercise}

All peak values of gas exchange parameters, workload, and the exhausted time were similar in the two supplement groups (Table 2). Note that the $\dot{\mathrm{V}}_{\mathrm{E}}, \dot{\mathrm{V}} \mathrm{O}_{2}, \dot{\mathrm{V}} \mathrm{CO}_{2}$, $\mathrm{HR}$, and $\mathrm{R}$ responses increased in proportion to the increasing work rate (time effect, all $\left.p<0.001, \eta^{2}=0.917-0.993\right)$ and only $\dot{\mathrm{V}}_{\mathrm{E}}$ showed a significant difference between the HCP and placebo groups at some work rates (interaction effect: $\mathrm{F}(11,110)=2.206, p=0.019$, $\eta^{2}=0.181$ ), as illustrated in Figure 1. The metabolic parameters of $\dot{\mathrm{VO}}_{2}$ and $\dot{\mathrm{VCO}}_{2} \mathrm{HR}$ and $\mathrm{R}$ were quite similar in the two conditions at all work rates (Figure 1B-E). $\mathrm{P}_{\mathrm{ET}} \mathrm{CO}_{2}$ first increased from 20 to $120 \mathrm{~W}$ then decreased from 160 to $240 \mathrm{~W}$ despite the lack of a significant difference between the HCP and placebo groups (Figure 1F).

A main effect of supplement was noted in the form of a lower $\mathrm{pH}$ (supplement effect: $\mathrm{F}(1,15)=4.879, p=0.043, \eta^{2}=0.245$ ) and a higher $\mathrm{HCO}_{3}{ }^{-}$(supplement effect: $\mathrm{F}(1,15)=5.762$, $p=0.030, \eta^{2}=0.278$ ) between the HCP and placebo groups during incremental exercise (Figure 2A,C). The change in Lac was similar between the two groups, which might be due to a greater $\mathrm{HCO}_{3}{ }^{-}$value as an index of buffering capacity, which was supported by our observation of a lower AGap in the HCP group compared to the placebo group (Figure 2D).

Table 2. Peak values of gas exchanges parameters, workload, and the exhausted time during incremental exercise between the HCP and placebo groups.

\begin{tabular}{cccc}
\hline Metabolic Gas Exchange & HCP & Placebo & P Value \\
\hline $\mathrm{V}_{\mathrm{E}}\left(\mathrm{L} \cdot \mathrm{min}^{-1}\right)$ & $115.2 \pm 24.3$ & $114.7 \pm 28.8$ & 0.918 \\
$\mathrm{VO}_{2}\left(\mathrm{~mL} \cdot \mathrm{min}^{-1}\right)$ & $3119 \pm 423$ & $3141 \pm 546$ & 0.716 \\
$\mathrm{VCO}_{2}\left(\mathrm{~mL} \cdot \mathrm{min}^{-1}\right)$ & $3496 \pm 576$ & $3528 \pm 702$ & 0.721 \\
$\mathrm{HR}\left(\right.$ beats$\left.\cdot \mathrm{min}^{-1}\right)$ & $178.1 \pm 6.9$ & $179.2 \pm 8.3$ & 0.383 \\
$\mathrm{R}$ & $1.1 \pm 0.1$ & $1.1 \pm 0.1$ & 0.859 \\
Workload $(\mathrm{W})$ & $270 \pm 34$ & $272 \pm 29$ & 0.430 \\
Exhausted Time (min) & $26.8 \pm 4.0$ & $26.9 \pm 3.9$ & 0.701
\end{tabular}

Data are shown as mean \pm standard deviation (SD). 

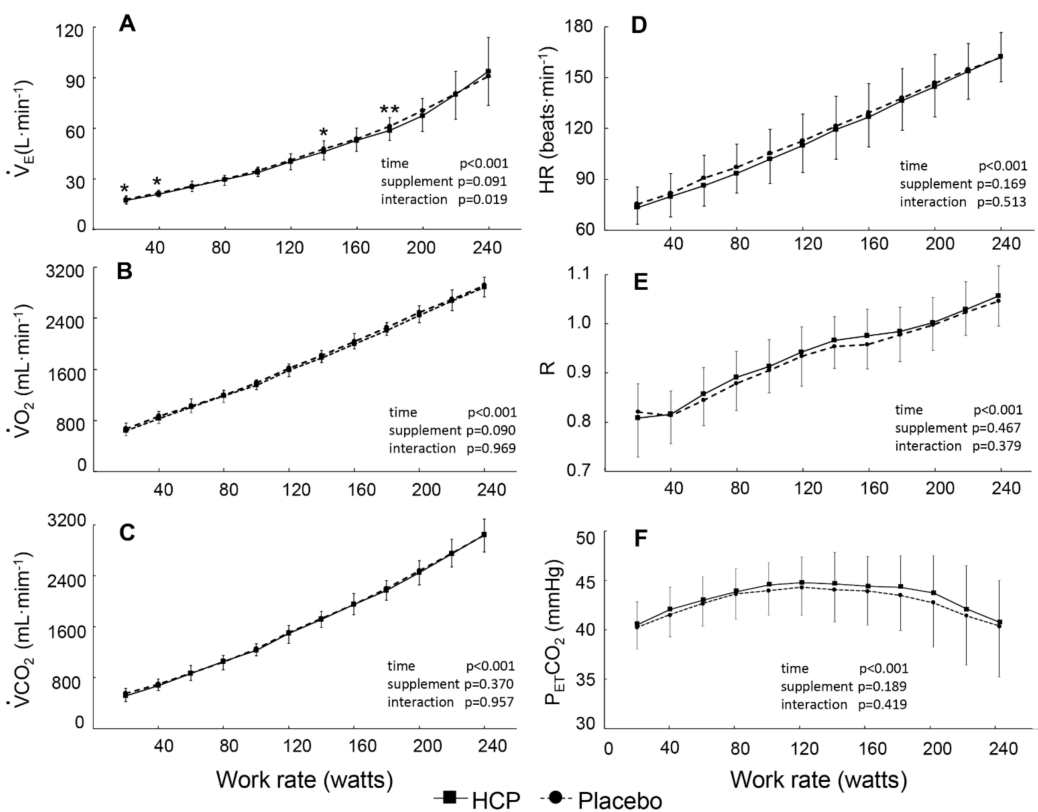

Figure 1. Group mean values of pulmonary ventilation $\left(\dot{\mathrm{V}}_{\mathrm{E}}\right)(\mathbf{A}), \mathrm{O}_{2}$ uptake $\left(\dot{\mathrm{VO}}_{2}\right)(\mathbf{B}), \mathrm{CO}_{2}$ output $\left(\dot{\mathrm{VCO}}{ }_{2}\right)(\mathrm{C})$, heart rate $(\mathrm{HR})(\mathrm{D})$, gas exchange ratio $(\mathrm{R})(\mathrm{E})$, and end-tidal $\mathrm{CO}_{2}$ pressure $\left(\mathrm{P}_{\mathrm{ET}} \mathrm{CO}_{2}\right)$ (F) versus the power output during the cycle exercise in the HCP and placebo groups. Error bars: SD. The significant difference between HCP and placebo at higher work rates is shown; ${ }^{*} p<0.05$, ** $p<0.01$.
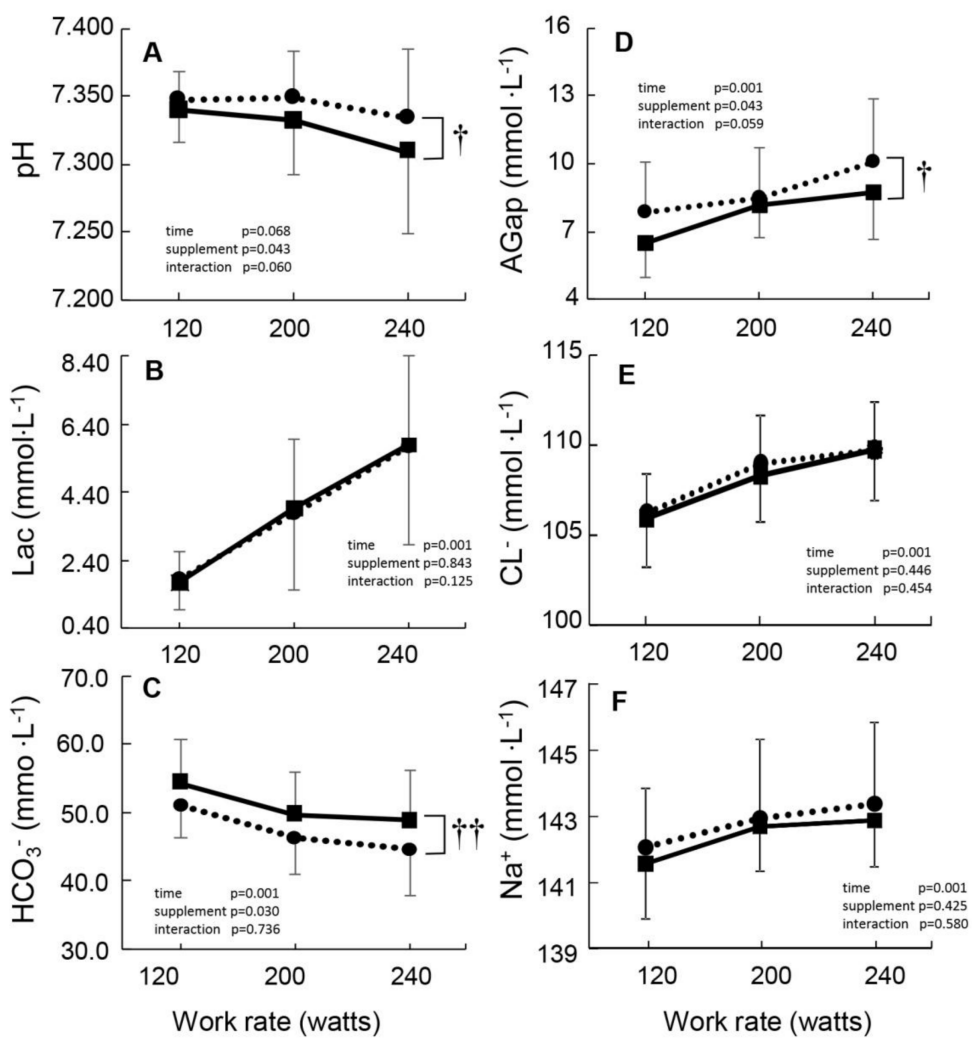

- $\mathrm{HCP}$

- Placebo

Figure 2. Group mean values of peripheral venous blood $\mathrm{pH}(\mathbf{A})$, lactate (Lac) (B), bicarbonate $\left(\mathrm{HCO}_{3}{ }^{-}\right)(\mathbf{C})$, aniongap (AGap) (D), chloride $\left(\mathrm{Cl}^{-}\right)(\mathbf{E})$, and sodium $\left(\mathrm{Na}^{+}\right)(\mathbf{F})$ with the function of different work rates during the cycle exercise in the HCP and placebo groups. Error bars: SD. Significant difference between HCP and placebo at higher work rates $+p<0.05,+\uparrow p<0.01$. 
In the $\mathrm{VL}$ muscles of the subjects, even though the deoxy $[\mathrm{Hb}+\mathrm{Mb}]$ and total[ $\mathrm{Hb}+\mathrm{Mb}]$ increased with the work rates $(p<0.001$, Figure $3 \mathrm{~A}, \mathrm{~B})$, the $\mathrm{S}_{\mathrm{t}} \mathrm{O}_{2}$ was kept constant throughout the incremental exercise at a given work rate (time effect: $\mathrm{F}(11,121)=0.791, p=0.648$, $\eta^{2}=0.067$, Figure $\left.3 \mathrm{C}\right)$. The deoxy[Hb $\left.\mathrm{Mb}\right]$ and total[ $\left.\mathrm{Hb}+\mathrm{Mb}\right]$ values did not differ between the HCP and placebo groups at a given work rate. In contrast, the deoxy[ $\mathrm{Hb}+\mathrm{Mb}]$ value in the RF muscles of the subjects was significantly greater from 200 to $240 \mathrm{~W}$ in the HCP group compared to the placebo group (interaction effect: $F(11,121)=2.726$, $p=0.004, \eta^{2}=0.199$, Figure 3D). The total[ $\left.\mathrm{Hb}+\mathrm{Mb}\right]$ profile in the $\mathrm{VL}$ muscle was affected by deoxy $[\mathrm{Hb}+\mathrm{Mb}]$, although there was not a significant interaction between the HCP and placebo groups (interaction effect: $\mathrm{F}(11,121)=1.781, p=0.064, \eta^{2}=0.13$, Figure 3E). The $\mathrm{S}_{\mathrm{t}} \mathrm{O}_{2}$ tended to decrease with the work rates from approx. $57 \%$ to $45 \%$ (time effect: $\mathrm{F}(11,121)=1.469, p=0.152, \eta^{2}=0.118$, Figure $\left.3 \mathrm{~F}\right)$ with lower mean values in the HCP group compared to the placebo group (supplement effect: $\mathrm{F}(1,11)=4.405, p=0.060$, $\eta^{2}=0.286$ ). Regarding the RF muscle, muscle deoxygenation would be promoted by the $\mathrm{HCP}$ supplement, providing greater deoxy[Hb $+\mathrm{Mb}]$ and lower muscle $\mathrm{S}_{\mathrm{t}} \mathrm{O}_{2}$ values.
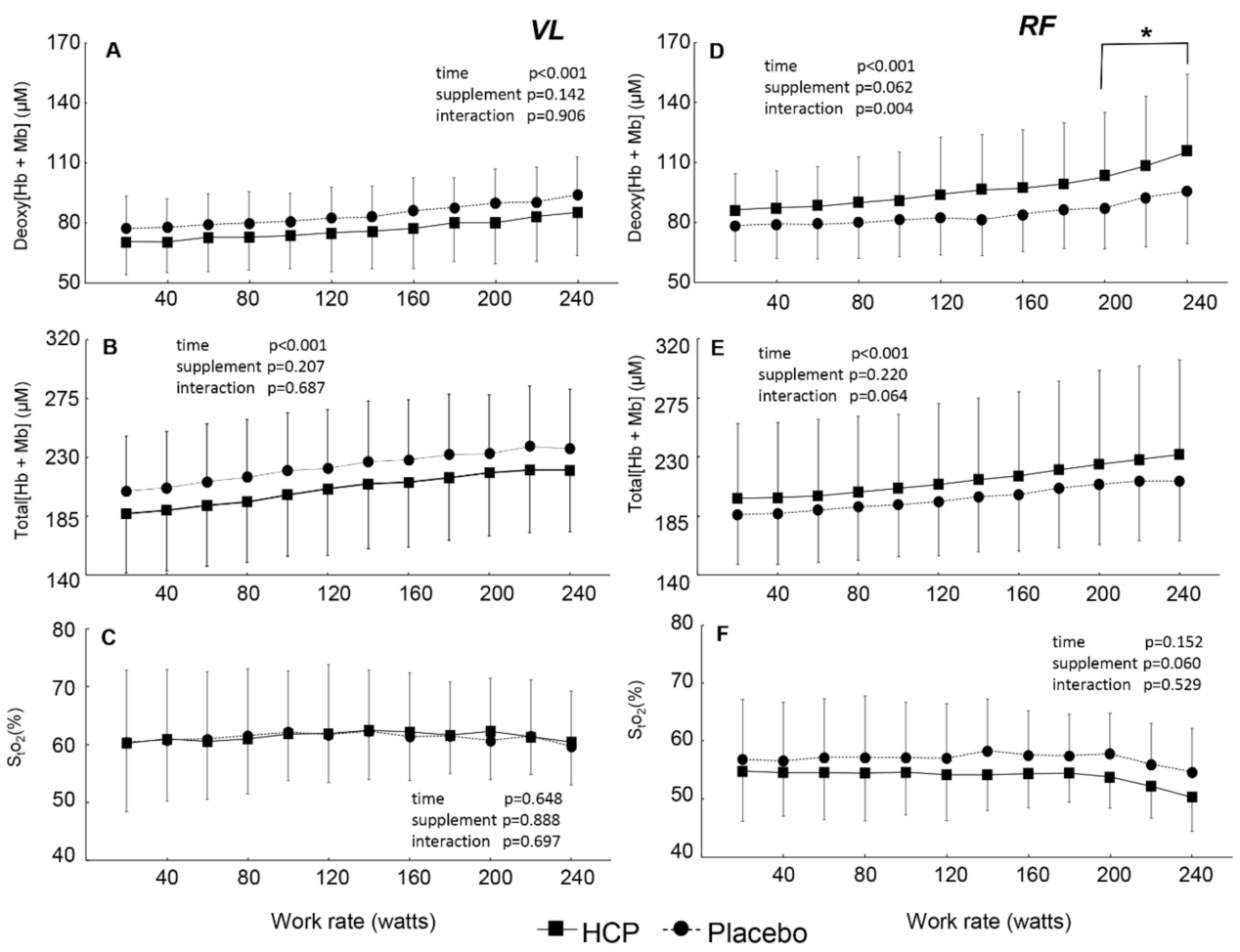

Figure 3. Group mean values for the vastus lateralis (VL) muscle deoxygenated hemoglobin and myoglobin concentration (deoxy $[\mathrm{Hb}+\mathrm{Mb}])(\mathbf{A})$, total hemoglobin and myoglobin concentration (total[ $\mathrm{Hb}$ $+\mathrm{Mb}])(\mathbf{B})$, tissue $\mathrm{O}_{2}$ saturation $\left(\mathrm{S}_{\mathrm{t}} \mathrm{O}_{2}\right)(\mathbf{C})$, and rectus femoris (RF) muscle deoxy[Hb $\left.+\mathrm{Mb}\right](\mathbf{D})$, total $[\mathrm{Hb}+\mathrm{Mb}](\mathbf{E})$, and $\mathrm{S}_{\mathrm{t}} \mathrm{O}_{2}(\mathbf{F})$ versus the power output during cycle exercise in the $\mathrm{HCP}$ and placebo groups. Error bars: SD. Significant difference between HCP and placebo at higher work rates; ${ }^{*} p<0.05$.

The slope of the relationship between the $\dot{\mathrm{V}}_{\mathrm{E}}$ and deoxy $[\mathrm{Hb}+\mathrm{Mb}]$ profiles was steeper in the HCP group (slope $=0.367$ ) compared to the placebo group (slope $=0.227)$ (Figure 4 ), which means that the depressed $\dot{\mathrm{V}}_{\mathrm{E}}$ using $\mathrm{HCP}$ promotes working muscle deoxygenation (especially in the RF muscle) during incremental exercise as well as rest. 


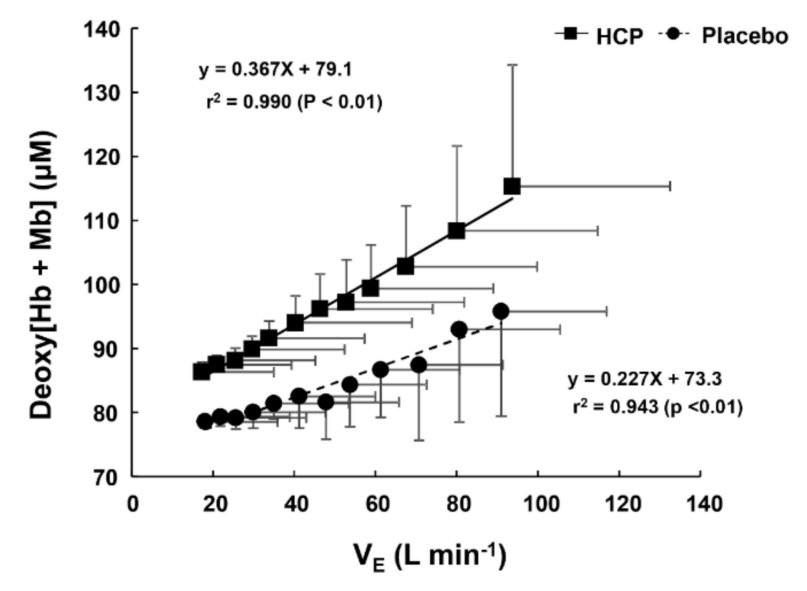

Figure 4. The relationship between ventilation $\left(\dot{\mathrm{V}}_{\mathrm{E}}\right)$ and the rectus femoris $(\mathrm{RF})$ muscle deoxygenated hemoglobin and myoglobin concentration (deoxy $[\mathrm{Hb}+\mathrm{Mb}]$ ) profiles during cycle exercise in the $\mathrm{HCP}$ and placebo groups. Note that the regression line for $\dot{\mathrm{V}}_{\mathrm{E}}-\mathrm{deoxy}[\mathrm{Hb}+\mathrm{Mb}]$ profiles' relationship was steeper in the HCP group (slope $=0.367$ ) than in the placebo group (slope $=0.227$ ). Error bars: SD.

\section{Discussion}

To the best of our knowledge, the present study is the first investigation to use a form such as $\mathrm{HCP}$ capsules as a method of administering $\mathrm{H}_{2}$ (instead of $\mathrm{H}_{2}$ water or $\mathrm{H}_{2}$ gas) and to comprehensively investigate the effects of $\mathrm{HCP}$ by examining a wide spectrum of acid-status and metabolic status values in addition to the working muscle deoxygenation measured by TR-NIRS. The main finding of this study was that $\mathrm{H}_{2}$ in the form of $\mathrm{HCP}$ after three days of intake caused a slightly but significantly lower $\mathrm{pH}$ and greater $\mathrm{PCO}_{2}$ due to hypoventilation, which might be due to the reduced ventilatory responsiveness to $\mathrm{pH}$ by the consumption of HCP (Figure 5). The reduction in oxidative stress with antioxidant treatment may suppress the peripheral chemoreceptor response (i.e., inhibition) more than the central chemoreceptor response (i.e., stimulation) [32]. No similar observation was made thus far in previous research examining $\mathrm{H}_{2}$. In fact, quite the opposite effect was observed, as $\mathrm{H}_{2}$-infused water caused metabolic alkalosis, decreased the blood lactate level, and lowered the rate of perceived exertion (RPE) $[5,7,33]$.

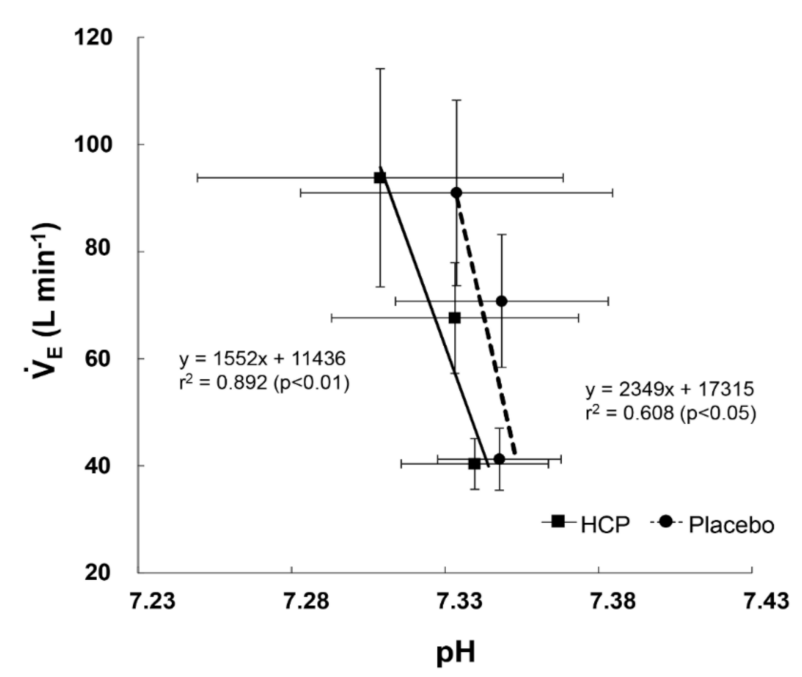

Figure 5. The relationship between ventilation $\left(\dot{\mathrm{V}}_{\mathrm{E}}\right)$ and $\mathrm{pH}$ profiles during the cycle exercise between the HCP and placebo group. Note that the regression line for the $\dot{\mathrm{V}}_{\mathrm{E}}-\mathrm{pH}$ profiles' relationship was steeper in the HCP group (slope $=0.892$ ) than in the placebo group (slope $=0.608$ ) as a function of the reduced chemoreflex drive to $\mathrm{pH}$ by the administration of HCP. Error bars: SD. 
The existing hypoventilation can be clarified by this study's results, as the mean values of $\mathrm{V}_{\mathrm{E}}$ at rest were significantly lower with $\mathrm{HCP}$ concomitant with a greater $\mathrm{PCO}_{2}$ compared to the placebo, suggesting hypoventilation, as seen by the lower $\dot{\mathrm{VO}}_{2}$ and $\dot{\mathrm{VCO}} \mathrm{C}_{2}$ (Table 1$)$. In addition, a significant difference was detected between the HCP and placebo groups, showing the presence of mitigated ventilation at rest that was apparent in the blood results of lower $\mathrm{pH}, \mathrm{PO}_{2}, \mathrm{SO}_{2}, \mathrm{Cl}$, and higher $\mathrm{PCO}_{2}$ and $\mathrm{HCO}_{3}{ }^{-}$with $\mathrm{HCP}$ compared to the placebo (Table 1). The decreased $\mathrm{pH}$ was most likely caused by the primary elevation in $\mathrm{PCO}_{2}$ as a result of suppressed ventilation [34] and, consequently, as lower pH caused the renal retention of bicarbonate. This is a compensatory mechanism to induce acidemia to maintain the balance $\mathrm{pH}$, and the end result is an increased concentration of bicarbonate and a decreased chloride concentration $[35,36]$.

During incremental exercise, a significantly lower $\dot{\mathrm{V}}_{\mathrm{E}}$ at some work rates was reflected by the ventilatory analysis values (Figure 1A) demonstrating the ongoing impact of HCP on the $\dot{\mathrm{V}}_{\mathrm{E}}$ response during incremental exercise as well. Despite that, the negative effect of HCP is eliminated in $\mathrm{VCO}_{2}$ and $\dot{\mathrm{VO}}_{2}$, as shown by the lack of significant changes in these parameters during exercise (Figure 1B,C); thus, the metabolic parameters increased proportionally to the work rate as a consequence of the increased respiratory and metabolic demands of the exercise [37]. At peak performance, HCP also had no effect on the exhausted exercise time or peak gas exchange parameters or on the subjects' HR (Table 2). Therefore, it has not yet been demonstrated that the ingestion of molecular hydrogen is effective for peak performance in trained subjects.

As a result of the increased $\dot{\mathrm{V}}_{\mathrm{E}}$ during the progressive exercise, the $\mathrm{Cl}$ depletion ceased (Figure 2E) and the blood $\mathrm{Cl}$ was normalized [35]. However, the changes in blood $\mathrm{pH}$ and $\mathrm{HCO}_{3}{ }^{-}$continued (Figure 2A,C), due to the continued hypoventilation despite the absence of significant differences in $\mathrm{P}_{\mathrm{ET}} \mathrm{CO}_{2}$ and lactate between the HCP and placebo groups. Consequently, the decreased AGap in the HCP subjects (Figure 2D) was influenced as a result of the corrected $\mathrm{Cl}$ but not $\mathrm{HCO}_{3}{ }^{-}$. In addition, no significant difference in Lac was observed at rest or during exercise between the HCP and placebo groups, which might have been due to the higher $\mathrm{HCO}_{3}{ }^{-}$acting as a buffer. Therefore, judging from the acid-base status (Figure 2A-C), it is likely that HCP enhances the lactic acid buffering capacity despite hypoventilation.

In the relationship between ROS and ventilation, we calculated the ventilatory responsiveness to $\mathrm{pH}$ using the mean values of $\dot{\mathrm{V}}_{\mathrm{E}}$ and $\mathrm{pH}$, and the ventilatory responsiveness to $\mathrm{pH}$ was reduced by the intake of HCP compared to placebo (Figure 5). Lee et al. (2009) showed that ventilatory sensitivity to hypercapnia following antioxidant administration was significantly reduced compared to placebo in patients with sleep apnea, which we speculated was a measure of the patients' central and peripheral chemoreflex sensitivity [38]. The reduced ventilatory responsiveness to $\mathrm{pH}$ or $\mathrm{CO}_{2}$ is associated with an increase in the $\mathrm{CO}_{2}$ reserve in the presence of changes in hypercapnic hypoventilation [39].

The LTF was reduced in patients with sleep apnea who were given an antioxidant cocktail, and it was suggested that the release of ROS may have a role in the induction and maintenance of LTF $[38,40]$.

Wilkerson et al. (2008) also demonstrated that an intravenous administration of $10 \mathrm{mg}$ of a superoxide anion scavenger to anesthetized, vagotomized, and ventilated rats before their exposure to acute hypoxia abolished the LTF of phrenic nervous activity [18], which led to lower ventilation. If LTF were active as a result of HCP, continued hyperventilation would be predicted, which is associated with ROS production [16,41]. In fact, we observed that the HCP supplementation clearly instigated lower $\mathrm{PO}_{2}$ and greater $\mathrm{PCO}_{2}$ values due to hypoventilation in our subjects, and we thus speculated that these physiological phenomena are probably caused by hypoventilation due to an excessive suppression of ROS production by HCP. The neuromodulation of LTF in humans is not well understood, and few studies have attempted to tackle this issue. However, additional research is necessary to determine the mechanisms responsible for modulating LTF in humans via antioxidant administration. 
Given these findings in animals and humans, there is a possibility that the ROS would be downregulated by the administration of molecular hydrogen and cause hypoventilation and blood hypercapnia. We thus hypothesized that an excessive administration of an antioxidant of molecular hydrogen would reduce the magnitude of the ventilatory response that was associated with the increase in the $\mathrm{CO}_{2}$ reserve before and during exhausted exercise in humans.

With the use of TR-NIRS during exercise, we observed different reactions in the HCP and placebo subjects depending on the muscle site, which can be attributed to the differing recruitment of fast-twitch muscle fibers (which are higher in the RF muscle) and slow-twitch muscle fibers (which are higher in the VL) [10,14,42].

In the RF muscle, we observed significantly greater deoxy[Hb $+\mathrm{Mb}]$ at rest and higher work rates during the incremental exercise by the administration of $\mathrm{HCP}$. The total[ $\mathrm{Hb}+\mathrm{Mb}]$ was also higher, mostly reflecting the significantly increased deoxy $[\mathrm{Hb}+\mathrm{Mb}]$ between the HCP and placebo groups, with an average total increase of $12 \mu \mathrm{M}$. The greater deoxy $[\mathrm{Hb}+\mathrm{Mb}]$ at the same work rates suggested that impairments in the $\dot{\mathrm{QO}}_{2} / \dot{\mathrm{VO}}_{2}$ ratio necessitated higher fractional $\mathrm{O}_{2}$ extractions to support any given change in the external work rate in this muscle. These observations suggest that the primary mechanism by which the RF achieved greater fractional $\mathrm{O}_{2}$ extraction at higher work rates in the HCP group was via elevated diffusive $\mathrm{O}_{2}$ conductance consequent to an increased microvascular [hematocrit] $[14,43]$. Indeed, the velocity of capillary red blood cells increases more with contractions in less-oxidative rat muscles [44], and faster red blood cell velocity is associated with a higher capillary hematocrit [45]. The RF muscle is more dependent on $\mathrm{O}_{2}$ extraction for a given degree of muscle activation compared to the VL muscle $[43,46]$.

As shown in Figure 4, the greater deoxy[ $\mathrm{Hb}+\mathrm{Mb}]$ concentrations as a function of ventilation in the HCP subjects might be attributed to increased oxygen extraction at hypoventilation that accompanies the greater recruitment of fast-twitch fibers [47]. In addition, the $\mathrm{S}_{\mathrm{t}} \mathrm{O}_{2}$ value in the RF muscle was lower with HCP compared to the placebo as a result of hypoventilation. Collectively, therefore, the present findings suggest that HCP exerted its greatest effects on the RF muscle at higher work rates where type II fiber recruitment would be expected to dominate [48].

In the VL muscle, the total $[\mathrm{Hb}+\mathrm{Mb}]$ and deoxy $[\mathrm{Hb}+\mathrm{Mb}]$ concentrations did not differ significantly between the placebo and HCP groups at any work rates. The $\mathrm{S}_{\mathrm{t}} \mathrm{O}_{2}$ value also did not differ significantly between the two supplement groups, and this can be attributed to the relative greater presence of slow-twitch fibers in VL muscle. Slow-twitch fibers have a greater number of capillaries around each fiber and show better vasodilatory dynamic control and better oxygen extraction compared to fast-twitch fibers [42,46]. In particular, the VL muscle appears to possess a greater $\dot{\mathrm{QO}}_{2} / \dot{\mathrm{VO}}_{2}$ ratio during exercise compared to the RF muscle $[14,49-51]$. It has been suggested that differences between the VL and RF muscles may emanate, in part, from higher blood flow [52-54] and a greater proportion of more highly oxidative type I fibers in the VL muscle [55].

\section{Study Limitations}

In our study, the HCP supplementation provided approx. $2.5 \mu \mathrm{g} /$ day of $\mathrm{H}_{2}$. However, although HCP has a smaller amount of $\mathrm{H}_{2}$ compared to $\mathrm{H}_{2}$-rich water $[5,33]$, the presence of a compensatory respiratory response suggests an abnormal intake/absorption of $\mathrm{H}_{2}$, thus indicating that ingesting $\mathrm{H}_{2}$ in a form like HCP capsules provides a possibly better delivery as it releases $\mathrm{H}_{2}$ continuously in the intestinal lumen, which might make it an appealing method of administering $\mathrm{H}_{2}$. However, further research is warranted to test these concepts.

Some study limitations must be considered when interpreting the present results, including the small number of available investigations of hydrogen during exercise. As mentioned earlier, the present study is the first to use a form like HCP as a method of administering $\mathrm{H}_{2}$, and further research is needed to better comprehend the working conditions and limitations of delivery methods such as HCP. A further examination of the respiratory gas 
and blood sampling at rest with different durations of supplementation prior to exercise and post-exercise recovery might have shed further light on the mechanisms and actions of $\mathrm{H}_{2}$ in the form of HCP. Finally, we did not measure the level of ROS in the HCP intake. However, these limitations do not negate the important findings of this research.

\section{Conclusions}

$\mathrm{H}_{2}$-rich calcium powder supplementation, which increased the potential for antioxidantdependent slightly lower $\mathrm{pH}$ at rest, resulted in significantly lower $\dot{\mathrm{V}}_{\mathrm{E}}$ and $\mathrm{pH}$ status during the incremental exercise compared to placebo. The gas exchange status of $\mathrm{VCO}_{2}$ and $\mathrm{VO}_{2}$ were not affected by HCP. In addition, the HPC induced a significantly lower $\mathrm{O}_{2}$ delivery/utilization ratio at the RF muscle site but not in the VL muscle, which may be explained by these sites possessing inherently different vascular and metabolic control properties, perhaps related to their fiber-type composition.

Author Contributions: A.A.D.A. and N.E. were responsible for the design and conception of the work. A.A.D.A., T.H., S.N., and Y.F. were responsible for the data acquisition and analysis, and all authors were responsible for the interpretation of the data. T.H., as a clinician, managed the subjects condition before and after they took the supplement. A.A.D.A., N.E., and Y.F. drafted the work and all authors revised it critically for important intellectual content, approved the final version to be published, and agreed to be accountable for all aspects of the work. All authors have read and agreed to the published version of the manuscript.

Funding: Support for this study was provided by The Japan Society for the Promotion of Science and the Ministry of Education, Science, and Culture of Japan (No. 18K10909 NE, No. 19 H04022 to Y.F.).

Institutional Review Board Statement: Our study conformed to the Declaration of Helsinki, and the ethical committee of Doshisha University approved all study procedures (No. 18012).

Informed Consent Statement: Written, informed consent was obtained from all subjects after a detailed explanation of all procedures, the purpose of the study, the possible risks, and the benefits of participation.

Acknowledgments: The authors would like to thank all the subjects who volunteered for this study.

Conflicts of Interest: Author N.E. has received a research grant from ENAGEGATE Inc. We were provided with HCP supplements and a placebo by ENAGEGATE Inc. However, this company had no role in study design, data collection and analysis, decision to publish, or preparation of the manuscript.

\section{References}

1. Huang, C.S.; Kawamura, T.; Toyoda, Y.; Nakao, A. Recent advances in hydrogen research as a therapeutic medical gas. Free Radical. Res. 2010, 44, 971-982. [CrossRef]

2. Fritsch, J.; Lenz, O.; Friedrich, B. Structure, function and biosynthesis of $\mathrm{O}_{2}$-tolerant hydrogenases. Nature Rev. Microbiol. 2013, 11, 106-114. [CrossRef] [PubMed]

3. Hong, Y.; Chen, S.; Zhang, J.M. Hydrogen as a selective antioxidant: A review of clinical and experimental studies. J. Int. Med. Res. 2010, 38, 1893-1903. [CrossRef] [PubMed]

4. Ohta, S. Molecular hydrogen as a preventive and therapeutic medical gas: Initiation, development and potential of hydrogen medicine. Pharmacol. Ther. 2014, 144, 1-11. [CrossRef] [PubMed]

5. Ostojic, S.M. Molecular hydrogen in sports medicine: New therapeutic perspectives. Int. J. Sports Med. 2014, 36, 273-279. [CrossRef] [PubMed]

6. Ohsawa, I.; Ishikawa, M.; Takahashi, K.; Watanabe, M.; Nishimaki, K.; Yamagata, K.; Katsura, K.; Katayama, Y.; Asoh, S.; Ohta, S. Hydrogen acts as a therapeutic antioxidant by selectively reducing cytotoxic oxygen radicals. Nat. Med. 2007, 13, 688-694. [CrossRef] [PubMed]

7. Aoki, K.; Nakao, A.; Adachi, T.; Matsui, Y.; Miyakawa, S. Pilot study: Effects of drinking hydrogen-rich water on muscle fatigue caused by acute exercise in elite athletes. Med. Gas Res. 2012, 2. [CrossRef] [PubMed]

8. Koga, S.; Poole, D.C.; Fukuoka, Y.; Ferreira, L.F.; Kondo, N.; Ohmae, E.; Barstow, T.J. Methodological validation of the dynamic heterogeneity of muscle deoxygenation within the quadriceps during cycle exercise. Am. J. Physiol. Regul. Integr. Comp. Physiol. 2011, 301, 534-541. [CrossRef]

9. Koga, S.; Poole, D.C.; Ferreira, L.F.; Whipp, B.J.; Kondo, N.; Saitoh, T.; Ohmae, E.; Barstow, T.J. Spatial heterogeneity of quadriceps muscle deoxygenation kinetics during cycle exercise. J. Appl. Physiol. 2007, 103, 2049-2056. [CrossRef] 
10. Chin, L.M.; Kowalchuk, J.M.; Barstow, T.J.; Kondo, N.; Amano, T.; Shiojiri, T.; Koga, S. The relationship between muscle deoxygenation and activation in different muscles of the quadriceps during cycle ramp exercise. J. Appl. Physiol. 2011, 111, 1259-1265. [CrossRef]

11. Bowen, T.S.; Rossiter, H.B.; Benson, A.P.; Amano, T.; Kondo, N.; Kowalchuk, J.M.; Koga, S. Slowed oxygen uptake kinetics in hypoxia correlate with the transient peak and reduced spatial distribution of absolute skeletal muscle deoxygenation. Exp. Physiol. 2013, 98, 1585-1596. [CrossRef] [PubMed]

12. Spencer, M.D.; Amano, T.; Kondo, N.; Kowalchuk, J.M.; Koga, S. Muscle $\mathrm{O}_{2}$ extraction reserve during intense cycling is site-specific. J. Appl. Physiol. 2014, 117, 1199-1206. [CrossRef] [PubMed]

13. Fukuoka, Y.; Poole, D.C.; Barstow, T.J.; Kondo, N.; Nishiwaki, M.; Okushima, D.; Koga, S. Reduction of VO 2 slow component by priming exercise: Novel mechanistic insights from time-resolved near-infrared spectroscopy. Physiol. Rep. 2015, 3, e12432. [PubMed]

14. Okushima, D.; Poole, D.C.; Rossiter, H.B.; Barstow, T.J.; Kondo, N.; Ohmae, E.; Koga, S. Muscle deoxygenation in the quadriceps during ramp incremental cycling: Deep vs. superficial heterogeneity. J. Appl. Physiol. 2015, 119, 1313-1319. [CrossRef]

15. Okushima, D.; Poole, D.C.; Barstow, T.J.; Rossiter, H.B.; Kondo, N.; Bowen, T.S.; Amano, T.; Koga, S. Greater VO 2 peak is correlated with greater skeletal muscle deoxygenation amplitude and hemoglobin concentration within individual muscles during ramp-incremental cycle exercise. Physiol. Rep. 2016, 4, e13065. [CrossRef]

16. Peng, Y.J.; Overholt, J.L.; Kline, D.; Kumar, G.K.; Prabhakar, N.R. Induction of sensory long-term facilitation in the carotid body by intermittent hypoxia: Implications for recurrent apneas. Proc. Natl. Acad. Sci. USA 2003, 100, 10073-10078. [CrossRef]

17. Peng, Y.J.; Prabhakar, N.R. Effect of two paradigms of chronic intermittent hypoxia on carotid body sensory activity. J. Appl. Physiol. 2004, 96, 1236-1242. [CrossRef]

18. Wilkerson, J.E.; Satriotomo, I.; Baker-Herman, T.L.; Watters, J.J.; Mitchell, G.S. Okadaic acid-sensitive protein phosphatases constrain phrenic long-term facilitation after sustained hypoxia. J. Neurosci. 2008, 28, 2949-2958. [CrossRef]

19. Fabre, N.; Mourot, L.; Zerbini, L.; Pellegrini, B.; Bortolan, L.; Schena, F. A novel approach for lactate threshold assessment based on rating of perceived exertion. Int. J. Sports Physiol. Perform. 2013, 8, 263-270. [CrossRef]

20. Green, J.M.; McIntosh, J.R.; Hornsby, J.; Timme, L.; Gover, L.; Mayes, J.L. Effect of exercise duration on session RPE at an individualized constant workload. Eur. J. Appl. Physiol. 2009, 107, 501-507. [CrossRef]

21. Grocott, M.P.; Martin, D.S.; Levett, D.Z.; McMorrow, R.; Windsor, J.; Montgomery, H.E. Caudwell Xtreme Everest Research Group. Arterial blood gases and oxygen content in climbers on Mount Everest. N. Engl. J. Med. 2009, 360, 140-149. [CrossRef] [PubMed]

22. Fukuoka, Y.; Iihoshi, M.; Nazunin, J.T.; Abe, D.; Fukuba, Y. Dynamic characteristics of ventilatory and gas exchange during sinusoidal walking in humans. PLoS ONE 2017, 12, e0168517. [CrossRef] [PubMed]

23. Ebine, N.; Ahad-Abdulkarim, D.A.; Miyake, Y.; Hojo, T.; Abe, D.; Horiuchi, M.; Fukuoka, Y. Influence of age on cardiorespiratory kinetics during sinusoidal walking in humans. Front. Physiol. 2018, 9, 1191. [CrossRef] [PubMed]

24. Beaver, W.L.; Lamarra, N.; Wasserman, K. Breath-by-breath measurement of true alveolar gas exchange. J. Appl. Physiol. Respir. Environ. Exerc. Physiol. 1981, 51, 1662-1675. [CrossRef] [PubMed]

25. Hamaoka, T.; Katsumura, T.; Murase, N.; Nishio, S.; Osada, T.; Sako, T.; Higuchi, H.; Kurosawa, Y.; Shimomitsu, T.; Miwa, M.; et al. Quantification of ischemic muscle deoxygenation by near infrared time-resolved spectroscopy. J. Biomed. Opt. 2000, 5, 102-105. [CrossRef]

26. Ijichi, S.; Kusaka, T.; Isobe, K.; Okubo, K.; Kawada, K.; Namba, M.; Okada, H.; Nishida, T.; Imai, T.; Itoh, S. Developmental changes of optical properties in neonates determined by near-infrared time-resolved spectroscopy. Pediatr. Res. 2005, 58, 568-573. [CrossRef]

27. Ferreira, L.F.; Townsend, D.K.; Lutjemeier, B.J.; Barstow, T.J. Muscle capillary blood flow kinetics estimated from pulmonary $\mathrm{O}_{2}$ uptake and near-infrared spectroscopy. J. Appl. Physiol. 2005, 98, 1820-1828. [CrossRef]

28. Ferreira, L.F.; Koga, S.; Barstow, T.J. Dynamics of noninvasively estimated microvascular $\mathrm{O}_{2}$ extraction during ramp exercise. J. Appl. Physiol. 2007, 103, 1999-2004. [CrossRef]

29. Wilkerson, D.P.; Koppo, K.; Barstow, T.J.; Jones, A.M. Effect of prior multiple-sprint exercise on pulmonary $\mathrm{O}_{2}$ uptake kinetics following the onset of perimaximal exercise. J. Appl. Physiol. 2004, 97, 1227-1236. [CrossRef]

30. Oda, M.; Yamashita, Y.; Nakano, T.; Suzuki, A.; Shimizu, K.; Hirano, I.; Shimomura, F.; Ohmae, E.; Suzuki, T.; Tsuchiya, Y. Near-infrared time resolved spectroscopy system for tissue oxygenation monitor. Proc. SPIE. 1999, 3579, 611-617.

31. Ohmae, E.; Ouchi, Y.; Oda, M.; Suzuki, T.; Nobesawa, S.; Kanno, T.; Yoshikawa, E.; Futatsubashi, M.; Ueda, Y.; Okada, H.; et al. Cerebral hemodynamics evaluation by near-infrared time-resolved spectroscopy: Correlation with simultaneous positron emission tomography measurements. NeuroImage 2006, 29, 697-705. [CrossRef] [PubMed]

32. Zakynthinos, S.; Katsaounou, P.; Karatza, M.; Roussos, C.; Vassilakopoulos, T. Antioxidants increase the ventilatory response to hyperoxic hypercapnia. Am. J. Respir. Crit. Care Med. 2007, 175, 62-68. [PubMed]

33. Ostojic, S.M.; Stojanovic, M.D. Hydrogen-rich water affected blood alkalinity in physically active men. Res. Sports Med. 2014, 22, 49-60. [CrossRef] [PubMed]

34. Kraut, J.A.; Kurtz, I. Mixed Acid-Base Disorders. Core Concepts in the Disorders of Fluid, Electrolytes and Acid-Base Balance; Springer: Berlin/Heidelberg, Germany, 2012; pp. 307-326.

35. Galla, J.H. Metabolic alkalosis. J. Am. Soc. Nephrol. 2000, 11, 369-375. [PubMed] 
36. Hadjikoutis, S.; Wiles, C.M. Venous serum chloride and bicarbonate measurements in the evaluation of respiratory function in motor neuron disease. QJM 2001, 94, 491-495. [CrossRef]

37. Guenette, J.A.; Sheel, A.W. Physiological consequences of a high work of breathing during heavy exercise in humans. J. Sci. Med. Sport 2007, 10, 341-350. [CrossRef] [PubMed]

38. Lee, D.S.; Badr, M.S.; Mateika, J.H. Progressive argumentation and ventilatory long-term facilitation are enhanced in sleep apnea patients and are mitigated by antioxidant administration. J. Physiol. 2009, 587, 5451-5467. [CrossRef]

39. Katayama, K.; Smith, C.A.; Henderson, K.S.; Dempsey, J.A. Chromic intermittent hypoxia increases the $\mathrm{CO}_{2}$ reserve in sleeping dogs. J. Appl. Physiol. 2007, 103, 1942-1949.

40. Mateika, J.H.; Narwani, G. Intermittent hypoxia and respiratory plasticity in humans and other animals: Does exposure to intermittent hypoxia promote or mitigate sleep apnea? Exp. Physiol. 2009, 94, 279-296. [CrossRef]

41. Cao, K.Y.; Zwillich, C.W.; Berthon-Jones, M.; Sullivan, C.E. Increased normoxic ventilation induced by repetitive hypoxia in conscious dogs. J. Appl. Physiol. 1992, 73, 2083-2088.

42. Iannetta, D.; Qahtani, A.; Millet, G.Y.; Murias, J.M. Quadriceps muscles $\mathrm{O}_{2}$ extraction and EMG breakpoints during a ramp incremental test. Front. Physiol. 2017, 8. [CrossRef] [PubMed]

43. Goulding, R.P.; Okushima, D.; Fukuoka, Y.; Marwood, S.; Kondo, N.; Poole, D.C.; Barstow, T.J.; Koga, S. Impact of supine versus upright exercise on muscle deoxygenation heterogeneity during ramp incremental cycling is site specific. Eur. J. Appl. Physiol. 2021, in press.

44. Dawson, J.M.; Tyler, K.R.; Hudlicka, O. A comparison of the microcirculation in rat fast glycolytic and slow oxidative muscles at rest and during contractions. Microvasc. Res. 1987, 33, 167-182. [CrossRef]

45. Kindig, C.A.; Richardson, T.E.; Poole, D.C. Skeletal muscle capillary hemodynamics from rest to contractions: Implications for oxygen transfer. J. Appl. Physiol. 2002, 92, 2513-2520. [CrossRef]

46. Dahmane, R.; Djordjevic, S.; Simunic, B.; Valencic, V. Spatial fiber type distribution in normal human muscle: Histochemical and tensiomyographical evaluation. J. Biomech. 2005, 38, 2451-2459. [CrossRef]

47. Kume, D.; Akahoshi, S.; Yamagata, T.; Wakimoto, T.; Nagao, N. Does voluntary hypoventilation during exercise impact EMG activity? SpringerPlus 2016, 5. [CrossRef]

48. Krustrup, P.; Söderlund, K.; Mohr, M.; González-Alonso, J.; Bangsbo, J. Recruitment of fibre types and quadriceps muscle portions during repeated, intense knee-extensor exercise in humans. Pflugers Arch. 2004, 449, 56-65. [CrossRef]

49. Koga, S.; Barstow, T.J.; Okushima, D.; Rossiter, H.B.; Kondo, N.; Ohmae, E.; Poole, D.C. Validation of a high-power, time-resolved, near-infrared spectroscopy system for measurement of superficial and deep muscle deoxygenation during exercise. J. Appl. Physiol. 2015, 118, 1435-1442. [CrossRef]

50. Koga, S.; Okushima, D.; Barstow, T.J.; Rossiter, H.B.; Kondo, N.; Poole, D.C. Near-infrared spectroscopy of superficial and deep rectus femoris reveals markedly different exercise response to superficial vastus lateralis. Physiol. Rep. 2017, 5. [CrossRef]

51. Koga, S.; Okushima, D.; Poole, D.C.; Rossiter, H.B.; Kondo, N.; Barstow, T.J. Unaltered $\mathrm{VO}_{2}$ kinetics despite greater muscle oxygenation during heavy-intensity two-legged knee extension versus cycle exercise in humans. Am. J. Physiol. Regul. Integr. Comp. Physiol. 2019, 317, R203-R213. [CrossRef]

52. Heinonen, I.; Kemppainen, J.; Kaskinoro, K.; Peltonen, J.E.; Borra, R.; Lindroos, M.M.; Oikonen, V.; Nuutila, P.; Knuuti, J.; Hellsten, Y.; et al. Comparison of exogenous adenosine and voluntary exercise on human skeletal muscle perfusion and perfusion heterogeneity. J. Appl. Physiol. 2010, 108, 378-386. [PubMed]

53. Kalliokoski, K.K.; Kemppainen, J.; Larmola, K.; Takala, T.O.; Peltoniemi, P.; Oksanen, A.; Ruotsalainen, U.; Cobelli, C.; Knuuti, J.; Nuutila, P. Muscle blood flow and flow heterogeneity during exercise studied with positron emission tomography in humans. Eur. J. Appl. Physiol. 2000, 83, 395-401. [CrossRef] [PubMed]

54. Kalliokoski, K.K.; Laaksonen, M.S.; Takala, T.O.; Knuuti, J.; Nuutila, P. Muscle oxygen extraction and perfusion heterogeneity during continuous and intermittent static exercise. J. Appl. Physiol. 2003, 94, 953-958. [CrossRef] [PubMed]

55. Lexell, J.; Henriksson-Larsén, K.; Sjöström, M. Distribution of different fibre types in human skeletal muscles. 2. A study of cross-sections of whole m. vastus lateralis. Acta Physiol. Scand. 1983, 117, 115-122. [CrossRef] [PubMed] 